\title{
MASYARAKAT SEBAGAI PENYEBAB TERJADINYA PENCEMARAN AIR DI KALIMANTAN SELATAN
}

\author{
Noraidarayanti \\ Prodi Pendidikan IPS Fakultas Keguruan dan Ilmu Pendidikan Universitas Lambung Mangkurat, \\ Banjarmasin 2021 \\ Email: 2010128220011@mhs.ulm.ac.id
}

\begin{abstract}
Abstrak
Pencemaran air sangat marak terjadi di Provinsi Kalimantan Selatan, pencemaran air ini disebabkan oleh pembuangan sampah disungai, pembuangan limbah oleh industri-industri perusahaan dan lain sebagainya. hal tersebut sangat besar dampaknya terhadap pencemaran air. Seperti yang kita ketahui masyarakat di Provinsi Kalimantan Selatan mayoritas memenuhi kebutuhan sehari-hari memanfaatkan air sungai. Namun sekarang karena beberapa sungai terdampak pencemaran air sehingga masyarakat tidak dapat memanfaatkan air sungai, walaupun ada beberapa masyarakat yang masih memanfaatkan air sungai. Hal tersebut akan berdampak bagi kesehatan masyarakat. Tujuan dari penulisan artikel ini memberikan gambaran ataupun penjelasan mengenai penyebab dari terjadinya pencemaran air, dengan menggunakan studi literatur dalam melakukan penulisan pada artikel ini. Pada penulisan artikel ini dapat menghasilkan pembahasan mengenai penyebab dari terjadinya pencemaran air dan keterkaitan antara masyarakat dengan pencemaran air yang terjadi di Kalimantan Selatan.
\end{abstract}

Kata Kunci: Permasalahan lingkungan, Pencemaran air, Kalimantan Selatan

\section{PENDAHULUAN}

Permasalahan lingkungan adalah persoalan yang sering terjadi di Indonesia, terutama di Provinsi Kalimantan Selatan. Salah satu permasalahan lingkungan yang terjadi adalah pencemaran air yang disebabkan oleh manusia itu sendiri dimana manusia membuang sampah 
sembarangan yang lalu mengakibatkan tanggul yang jebol sehingga air sungai meluap, menebang pohon sembarangan tanpa melakukan reboisasi kembali dan mengakibatkan tanah longsor, lalu adapun yang disebabkan oleh industri-industri yang membuang limbah sembarangan sehingga hal itu mengakibatkan tercemarnya lingkungan sekitar dan menjadi penyebab utama dari banjir. Sampah yang tidak dikelola dengan baik akan terjadi peumpukan diberbagai tempat dan mengakibatkan lingkungan yang tidak baik, sehingga air yang disebabkan oleh sampah tersebut dapat menimbulkan pencemaran air (Syaharuddin. 2020).

Kurangnya kesadaran masyarakat sangat berdampak bagi lingkungan sekitar terutama lingkungan perairan sekitar dimana yang berakibat banjir dan dapat merugikan masyarakat itu sendiri. Namun masyarakat belum cukup menyadari bahwa dari perilaku buruk merekalah yang dapat merugikan mereka sendiri (Syaharuddin. 2020). Misalnya seperti, masyarakat yang membuang limbah rumah tangga di sungai lalu mengakibatkan air sungai meluap sehingga terjadi banjir, kemudian banjir tersebut melanda masyarakat dan mengakibatkan rusaknya rumah. Hal ini merupakan bukti bahwa perilaku masyarakat itu sendiri yang mengakibatkan bencana. Maka dari itu, dalam penulisan artikel ini bertujuan untuk memberikan penjelasan mengenai penyebab dan dampak dari terjadinya pencemaran air.

\section{METODE}

Metode yang digunakan dalam penulisan artikel ini adalah dengan menggunakan metode kualitatif dimana dalam proses penulisan artikel ini menggunakan referensi dari berbagai jurnal, buku, artikel, dan lain sebagainya. Pada pencarian artikel, jurnal, dan buku diperoleh beberapa sumber yang dianggap relevan, dan menggunakan kata kunci: 1) Permasalahan lingkungan, 2) Sungai di Banjarmasin, 3) Banjir. Dari berbagai referensi ditelaah dan di simpulkan mulai dari bagian abstrak hingga bagian kesimpulan, bertujuan agar memperoleh informasi yang berkaitan dengan permasalahan lingkungan. 


\section{PEMBAHASAN}

Pengertian dari permasalahan lingkungan adalah permasalah yang ada di lingkungan, ataupun sesuatu yang tidak patut terjadi di sebuah lingkungan. Permasalahan lingkungan ini disebabkan oleh faktor alam maupun oleh masyarakat sekitar yang cenderung melakukan hal yang dapat berdampak bagi lingkungan misalnya seperti, membuang sampah sembarangan, menebang pohon liar, membangun bangunan ditempat yang tidak sepatutnya contohnya seperti menutup sungai-sungai dengan tanah lalu dibangun rumah dan lain sebagainya. Hal tersebut tanpa disadari juga merupakan perilaku yang dapat merusak lingkungan, mengapa dikatakan demikian, karena perilaku mereka dapat mengakibatkan tergenangnya air hujan dan dapat menyebabkan banjir karena pembuangan air sudah tertutup. Suatu lingkungan dapat dikatakan bersih apabila terdapat jalan yang bersih, tidak terdapat sampah di sungai, serta udara yang bersih, sehingga dapat membuat masyarakat sekitar hidup dengan sehat (Mutiani. 2017).

Hal yang sangat penting dalam sistem pengelolaan lingkungan hidup adalah dengan adanya sumber daya manusia pemerintahan yang seharusnya mempunyai pendirian yang kuat dalam perilaku ataupun dalam budaya organisasi (Nahruddin \& Tambajong, 2017). Sumber daya manusia yang memiliki kualitas berperan penting untuk mencapai keberhasilan dalam pencapaian tujuan dalam pembangunan yang direncanakan. Termasuk perencanaan yang berwawasan lingkungan yang mana dbutuhkan dengan respon yang efektif dan efisien dari sumber daya manusia pemerintahan yang ikut terlibat dalam pelaksanaan aktivitas tersebut.

Banjir disebabkan oleh oknum-oknum yang tidak bertanggung jawab membuang sampah kesungai tidak hanya beberapa sampah saja yang dibuang kesungai adapun yang membuang sisa-sisa bekas hewan qurban yang dibuang kesungai dan adapula yang membuang bangkai hewan kesungai. Hal ini tentunya sangat berdampak bagi pencemaran air dikarenakan air sungai tidak bersih lagi dan menjadi berbau. Selain itu adapun pihak-pihak industri yang membuang limbah hasil dari industri tersebut kesungai dan hal ini merupakan sesuatu yang merugikan warga sekitar tentunya. Dengan adanya pencemaran air berdampak sekali bagi masyarakat yang melakukan aktivitas sehari-hari hanya mengandalkan air sungai, hal tersebut tidak hanya berdampak pada warga yang merusak lingkungan saja, namun juga berdampak bagi 
warga yang menjaga lingkungan dan tidak membuang sampah (Nahruddin, Z. 2018). Pihak pemerintah Kalimantan Selatan juga mengupayakan untuk membersihkan sampah yang menyebar di kawasan sungai namun hal ini belum cukup efektif dikarenakan masih ada beberapa warga yang dengan sembarangannya membuang sampah di sungai. Selain itu banjir juga dapat terjadi karena faktor cuaca di mana curah hujan yang berkepanjangan mengakibatkan meluapnya air sungai dan mengakibatkan banjir. Untuk di provinsi Kalimantan Selatan sendiri banjir sering terjadi di wilayah Kabupaten Barito Kuala, Kabupaten Tanah Laut, Kabupaten Banjar, dan lain sebagainya.

Selain banjir membuang sampah sampah sembarangan juga sangat berdampak bagi pencemaran air. Pencemaran air merupakan salah satu ancaman yang sangat dikhawatirkan oleh masyarakat dikarenakan air merupakan sumber dari kehidupan masyarakat (Yulisa Mulyani, Deasy Arisanty. 2019). Dalam Peraturan Pemerintah No 20 Tahun 1990 mengenai pengendalian pndaparan air, pencemaran air dapat diartikan sebagai masuknya makhluk hidup, atau komponen lain ke dalam air yang disebabkan oleh perilaku manusia sehingga menyebabkan turunnya kualitas air dan menyebabkan air tidak berfungsi lagi. Seperti yang kita ketahui masyarakat di Kalimantan Selatan melakukan kegiatan sehari-hari seperti mandi, mencuci, hingga minum menggunakan air sungai, hal ini sangat beresiko bagi kesehatan masyarakat dimana dapat berakibat diare, dan lain sebagainya. di zaman sekarang masyarakat sudah tidak disarankan untuk meminum dengan menggunakan air sungai dikarenakan air sungai sekarang sudah cukup tercemar yang dimana banyak dari industri pabrik yang membuang limbah dari perusahaan tersebut dan menyebabkan air sungai tercemar. Pencemaran air adalah permasalahan lingkungan di daerah perairan yang disebabkan oleh menumpuknya sampah di sungai dan pembuangan limbah-limbah, ciri-ciri dari tercemarnya air sungai adalah sebagai berikut: (1) air sungai tampak berwarna, (2) air sungai tampak berbau, (3) air sungai tampak kotor (Yulisa Mulyani, Deasy Arisanty, Sidharta. 2019).

Selain itu pencemaran air juga dapat disebabkan oleh perusahaan industri yang (Adyatma. 2019). Banyak masyarakat yang masih memanfaatkan air sungai walaupun air sungai sudah tercemar, namun secara terpaksa beberapa masyarakat yang memanfaatkan air sungai tersebut dikarenakan faktor ekonomi yang tidak mencukupi untuk membeli air bersih. Hal ini dapat berdampak bagi kesehatan masyarakat seperti diare, alergi, dan lain sebagainya. Upaya 
yang dapat dilakukan untuk menangani pencemaran air adalah dengan menanamkan kesadaran pada masyarakat untuk tidak membuang sampah sembarangan, dan menegur nya hingga memberikan sanksi pada masyarakat yang masih saja membuang sampah ke sungai walaupun sudah ditegur, selain itu masyarakat juga bisa diajak gotong royong untuk membersihkan sampah-sampah yang ada disungai. membuang limbah ke sungai, hal ini mereka lakukan bertujuan untuk mengurangi biaya pengeluaran, namun hal ini sangat besar dampaknya bagi masyarakat sekitar.

Dimana limbah dari hasil industri dapat mengganggu kesehatan masyarakat dan dapat mengganggu ekosistem makhluk hidup yang hidup di sungai seperti ikan dan lain sebagainnya. Selain diakibatkan oleh pembuangan limbah industri, pencemaran air juga dapat disebabkan oleh kapal-kapal yang ada di perairan dan tongkang yang menyebabkan banyaknya minyak yang mengotori perairan dan menyebabkan bau pada air tersebut dan dapat menimbulkan pencemaran pada air tersebut. Selain itu pencemaran air juga dapat disebabkan oleh rumah pemotongan hewan yang membuang sisa-sisa dari hewan yang tidak dapat digunakan dibuang ke sungai, misalnya seperti membuang darah hewan, dan bahkan isi perut hewan tersebut yang tidak dapat digunakan dibuang ke sungai sehingga menjadi akibat dari pencemaran air yang menimbulkan air sungai menjadi bau dan bahkan kotor. Selain hal tersebut pencemaran air juga dapat disebabkan oleh lahan pertanian dan perkebunan, yang dimana para petani menggunakan pupuk hingga zat kimia pada tanaman tersebut yang jika terjadi hujan kemudian menyebabkan pencemaran air (Mroyono, A. 2020).

Berikut beberapa foto dari pencemaran air yang disebabkan oleh beberapa hal:

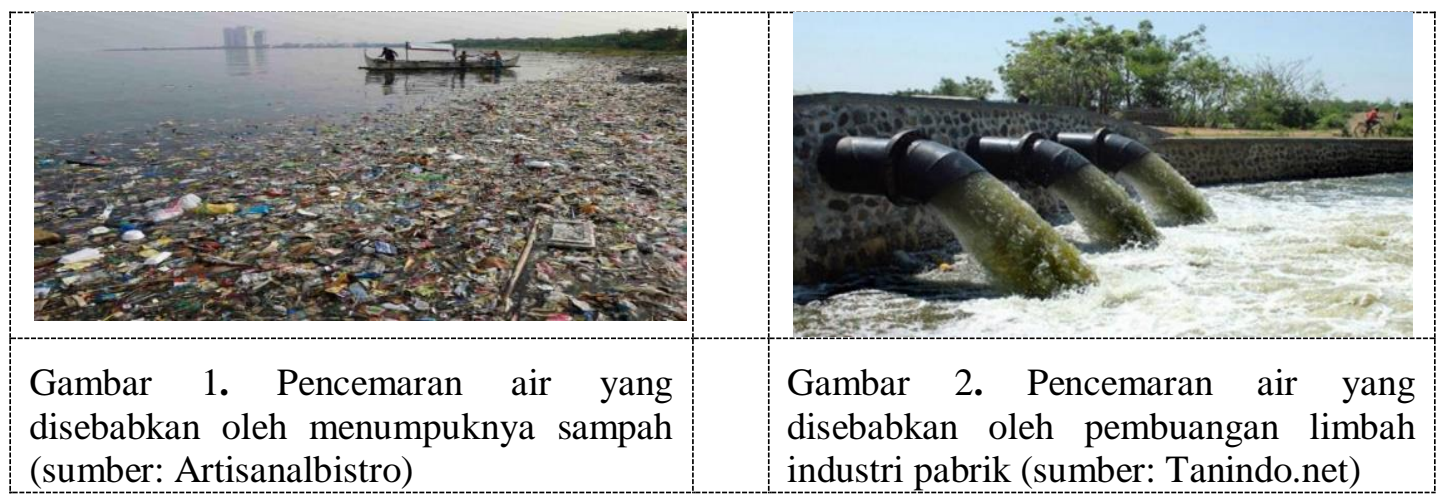


Pada gambar 1, merupakan pencemaran air yang mana disebabkan oleh masyarakat yang membuang sampah di sungai ataupun laut yang mayoritas dari sampah tersebut adalah sampah plastik yang dimana sistem penguraian nya lebih lama dibandingkan sampah yang lain dan menyebabkan penumpukan di suatu daerah perairan. Hal ini berdampak pada tercemarnya air sehingga menjadi kotor dan ikan-ikan yang hidup di daerah perairan tersebut hanya bisa memakan dari limbah tersebut sehingga sangat berbahaya untuk dikonsumsi masyarakat karena pakan dari hewan laut tersebut adalah sampah disekitarnya. Sedangkan pada gambar 2 adalah pencemaran air yang disebabkan oleh perusahaan industri terutama industri bahan kimia, industri detergen, industri makanan dan lain sebagainya. selain dari industri perusahaan pembuangan limbah juga dapat disebabkan oleh home industri atau bisa disebut industri rumahan. industri detergen, industri makanan dan lain sebagainya. selain dari industri perusahaan pembuangan limbah juga dapat disebabkan oleh home industri atau bisa disebut industri rumahan.

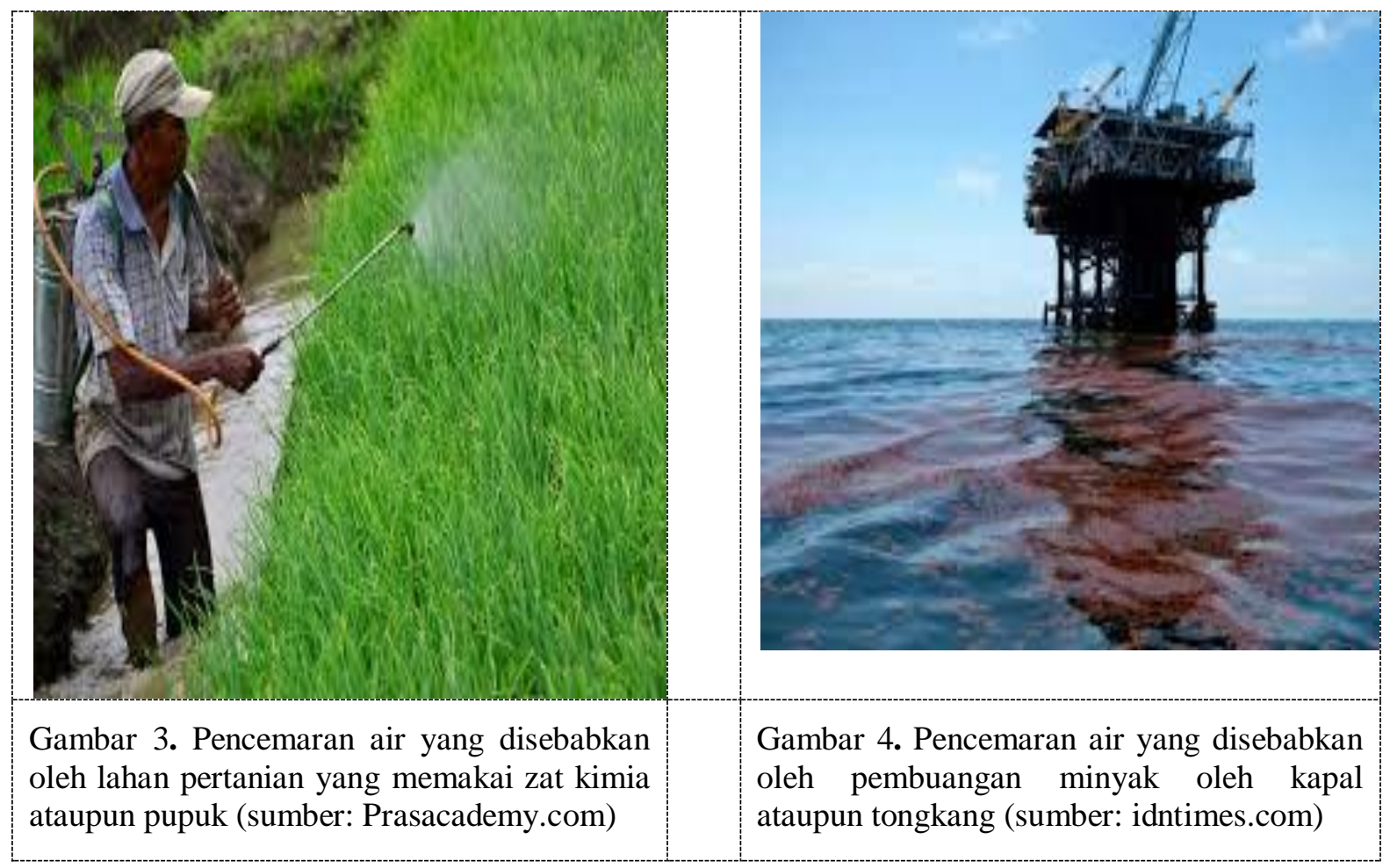


Pada gambar 3 merupakan pencemaran air yang disebabkan oleh lahan pertanian yang memakai zat kimia ataupun pupuk. Yang kemudian pada musim hujan tiba sehingga terjadilah peluapan air pada sekitar lahan pertanian kemudian dapat terjadi pencemaran air hal ini tentunya berdampak pada air yang tidak tampak bersih dan menjadi bau dikarenakan terkena pupuk dan zat kimia tersebut walaupun hal tersebut dilakukan tanpa disadari oleh petani tersebut. Hal ini berdampak besar bagi warga sekitar dimana para anak-anak suka mandi di sungai yang dekat dengan lahan pertanian dan bermain namun dikarenakan air telah tercemar tentunya hal tersebut sangat berdampak bagi kesehatan anak-anak tersebut. Selain anak-anak adapun warga sekitar yang masih menggunakan air sungai disekitar lahan pertanian untuk dijadikan air minum dan memasak hal ini berdampak pada kesehatan juga semisal diare dan alergi. Pada gambar ke 4 pencemaran air laut yang disebabkan oleh pembuangan minyak yang mana dilakukan oleh kapal dan tongkang, walaupun di laut tidak ada pemukiman warga namun hal tersebut berdampak besar bagi biota laut seperti rusaknya terumbu karang, matinya ikan-ikan serta hewan laut. Sehingga mengakibatkan kecilnya mata pencahariaan nelayan dan berdampak pada menurunnya ekonomi masyarakat, selain itu dengan rusaknya terumbu karang dapat menyebabkan tingginya kemungkinan tsunami disekitar laut tersebut dan tingginya gelombang yang terjadi pada laut tersebut. Selain dari beberapa akibat pencemaran air tersebut adapun dibuatnya empang-empang dan penangkaran ikan yang juga menyebabkan pencemaran air dikarenakan kotoran dari sisa pakan ikan tersebut lama kelamaan akan membentuk sebuah tumpukan yang dimana akan menjadikan hal tersebut sebagai faktor pencemaran air juga.

Dalam upaya penangan pencemaran air dapat dibagi menjadi dua hal yakni upaya penanganan melalui masyarakat itu sendiri dan upaya penanganan melalui pemerintah. Melalui masyarakat itu sendiri adalah dengan cara menanamkan rasa akan peduli dengan lingkungan, rasa akan peka akan lingkungan sehingga menimpulkan rasa cinta akan lingkungan. Dengan begitu dapat menyadarkan diri sendiri untuk berhenti membuat sampah di sungai dan enggan untuk mengotori sungai. Walaupun hal tersebut tidak terlalu efisien namun setidaknya dapat mengurangi pencemaran air yang ada di sekitar tersebut. Dengan begitu setidaknya untuk di waktu yang akan datang tidak ada pencemaran lalu tugas masyarakat tersebut dengan membersihkan pencemaran air yang telah terlanjur terjadi tersebut. Disini peran pemerintah cukup penting dimana pemerintah daerah dapat membuat program ataupun kegiatan untuk 
bebersih sungai seperti diadakan seminggu sekali mungkin, dengan mewajibkan masyarakat mengikuti kegiatan tersebut, dimulai dari gotong royong untuk membersihkan sampah di sekitar sungai, kemudian membersihkan sampah yang ada di sungai lalu setelah itu dapat dilakukan kegiatan menanam pohon disekitar sungai. Hal ini cukup efisien namun membutuhkan waktu yang cukup lama sehingga dapat terciptanya lingkungan perairan yang bersih dan asri. Walaupun di zaman sekarang pemerintah juga menetapkan peraturan seperti membuang sampah di sungai akan dikenakan hukuman dan memberhentikan penggunaan plastik pada pusat-pusat perbelanjaan, namun hal ini masih kurang efektif karena sampah plastik bukan hanya disebabkan oleh pusat perbelanjaan namun adapula kegiatan konsumsi masyarakat sehari-hari yang menggunakan plastik sehingga menimbulkan sampah plastik juga cukup marak. Upaya dalam mengurangi pencemaran air juga dapat dilakukan (1) melakukan penertiban pada pedagang yang bermukim di sekitar sungai, (2) memberikan pengetahuan kepada para pelaku UMKM bagaimana mengelola limbah dengan benar, (3) dalam pengawasan mengenai pembuangan limbah lebih ditingkatkan, (4) mengimplementasi kegiatan yang bertujun untuk mengendalikan pencemaran air sungai. (Benny Yohanner, Suyud Warno Utomo, Haruki Agustina. 2019). Betapa sedihnya, nasib seseorang yang menganggap remeh pencemaran air sungai, yang mana mengalir setiap saat didepannya. (Prof. M.P. Lambut, Ems. 2020).

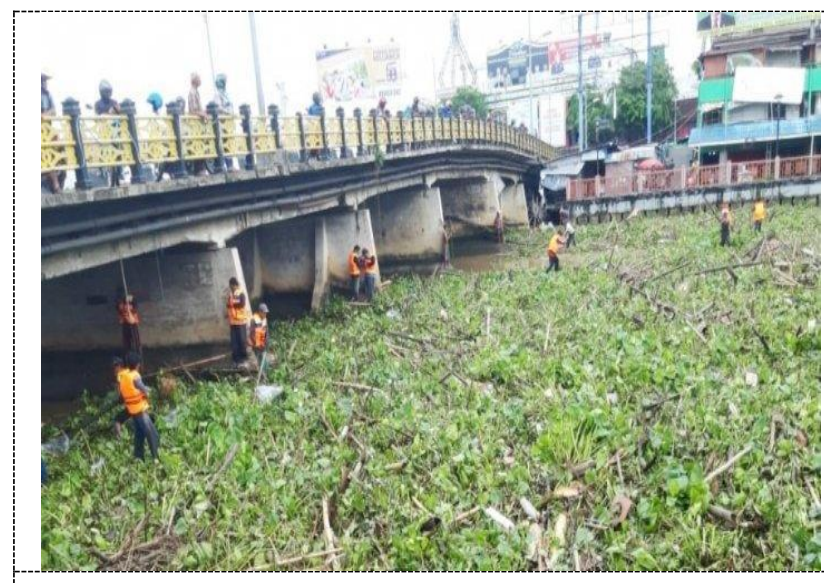

Gambar 5. Kegiatan membersihkan sampah yang menumpuk di sungai (sumber: kalsel.antaranews)

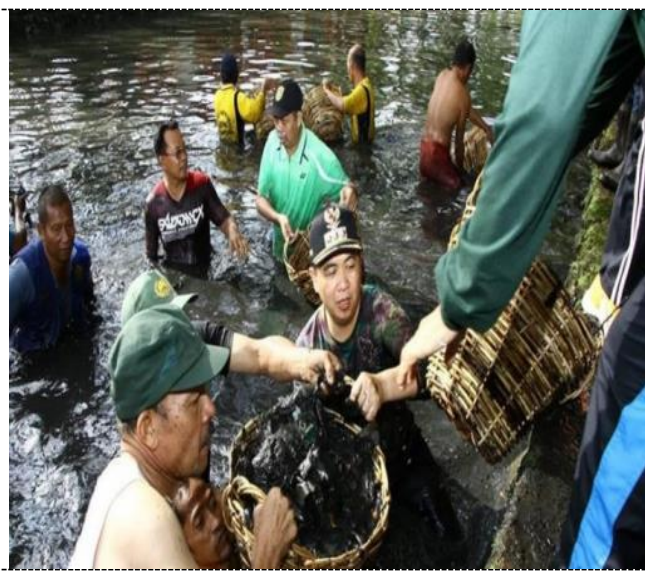

Gambar 6. Walikota Banjarmasin sedang melakukan kegiatan kerja bakti guna kebersihan sungai (sumber: kalsel.antaranews) 


\section{SIMPULAN}

Permasalahan lingkungan salah satunya adalah pencemaran air yang mana disebabkan oleh masyarakat yang membuang sampah di sungai, industri perusahaan membuang limbah kesungai, adapun industri rumahan yang membuang limbah kesungai, adapun juga petani yang menggunakan pupuk dan zat kimia sehingga terciptanya pencemaran air, serta pembuangan minyak yang dilakukan oleh kapal-kapal dan tongkang di laut. Hal ini sangat berdampak bagi lingkungan sekitar yang dimana dapat merugikan masyarakat terutama dalam hal kesehatan masyarakat itu sendiri. Upaya dalam permasalahan lingkungan tersebut adalah dengan cara tidak membuang sampah disungai dan menegur pihak-pihak terkait yang mencemari air disekitar tersebut.

Selain itu upaya dalam penanganan permasalahan lingkungan hal yang paling utama adalah adanya kesadaran masyarakat dalam menjaga dan memelihara lingkungan sekitar, serta bertanggung jawab dalam melindungi dan menggunakan lingkungan. Namun semua itu kembali lagi apapun permasalahan lingkungannya kesadaran masyarakat lah hal yang paling utama walaupun banyak metode untuk penanggulangan permasalahan pencemaran air, jika tidak diiringi dengan kesadaran masyarakat itu sendiri maka akan kembali terjadi lagi.

\section{DAFTAR PUSTAKA}

Abbas, E. W. (2015). Pendidikan IPS berbasis kearifan lokal. WAHANA Jaya Abadi.

Adilla, Y., Adyatma, S., \& Arisanty, D. (2016). Faktor Penyebab Kerentanan Kebakaran Berdasarkan Persepsi Masyarakat di Kelurahan Melayu Kecamatan Banjarmasin Tengah. Faktor Penyebab Kerentanan Kebakaran Berdasarkan Persepso Masyarakat Di Kelurahan Melayu Kecamatan Banjarmasin Tengah.

Hadi, S. (2021). Editor Buku "Peduli Sungai"- Sumasno Hadi.

Mryono, A. (2020). Menangani banjir, kekeringan dan lingkungan. UGM PRESS.

Mulyani, Y., Arisanty, D., \& Adyatma, S. (2021). POTENSI PENCEMARAN AKTIVITAS KERAMBA JARING APUNGG (KJA) TERHADAP SUNGAI MARTAPURA DI 
KELURAHAN BANUA ANYAR BANJARMASIN TIMUR. JPG (Jurnal Pendidikan Geografi, 6 (2).

Nahruddin, Z. (2018). Isu-Isu Strategis Permasalahan Lingkungan Hidup.

Norhayati, N., Abbas, E. W., \& Putra, M. A. H. (2019). Social Interaction Pattern Jelai Riverbanks South Basirih. The Innovation of Social Studies Journal 1(1), 1220.

Subiyakto, B., \& Mutiani, M, (2019). Internalisasi nilai pendidikan melalui aktivitas masyarakat sebagai sumber belajar ilmu pengetahuan sosial. Khazanah: Jurnal Studi Islam Dan Humaniora, 17 (1), 137-166.

Subiyakto, B., Abbas, E. W., Arisanty, D., Mutiani, M., \&Akmal, H. (2020). Sungai dan Kehidupan Masyarakat Banjar: Penguatan Lokalitas dalam Wacana Pendidikan IPS yang Responsif.

Syaharuddin, S. (2020). Laporan Pengabdian Kepada Masyarakat Pelatihan Pengelolaan Sampah Anorganik Menjadi Aneka Kreasi Daur Ulang Pada Remaja di Kampung Hijau Kelurahan Sungai Bilu.

Syahrin, M, A., Syaharuddin, S., \& Rahman, A. M. (2020). Environmental Awareness of Kampung Hijau Society, Sungai Bilu Banjarmasin. The Kalimantan Social Studies Journal, 1(2), 191- 200.

Yohanner, B. Y., Utomo, S. W., \& Agustina, H. (2019). Kajian Kualitas Air Sungai dan Upaya Pengendalian Pencemaran Aie. IJEEM-Indonesian Journal of Environmental Education and Management, 4(2), 136-155. 